\title{
Seeing the trees: Farmer perceptions of indigenous forest trees within the cultivated cocoa landscape
}

\author{
by Jane E. Atkins ${ }^{1}$ and Ivan Eastin ${ }^{2}$
}

\begin{abstract}
Throughout Ghana's high forest zone, cocoa farmers clear secondary or primary forest to establish new farms, capturing the capacity of nutrient-rich forest soils to increase cocoa yields. However, many cocoa farmers preserve remnant forest trees on existing farms as an integral and necessary component of the production landscape, making decisions about tree removal and tree retention based on a unique set of selection criteria. How they perceive trees plays a crucial role in daily management decisions made at the micro level, which in turn influence landscape patterns on the macro level. The central question of this research relates to how Ghanaian farmers perceive forest trees within the cultivated cocoa landscape. The research data were collected using an exploratory case study approach that combined ethnographic and survey techniques, and draws on 34 farmer interviews, 34 farm surveys, and interviews with key informants representing diverse stakeholder interests in the Domeabra Traditional Lands, Ashanti-Akim in south central Ghana. The research data were analyzed to identify the important functions of forest trees as perceived by study participants, both as a biophysical component within the farm ecosystem and as an input to the rural economy.
\end{abstract}

Key words: cocoa landscape, attitudes and perceptions of trees, tree retention, Ghana cocoa farming, cocoa canopy

\section{RÉSUMÉ}

Dans la région des forêts de haute montagne du Ghana, les producteurs de cacao déboisent la forêt secondaire ou primaire pour créer de nouvelles fermes, tirant profit de la productivité des sols forestiers riches en éléments nutritifs pour accroître les rendements de la production de cacao. Cependant, plusieurs producteurs de cacao conservent les arbres forestiers résiduels dans les fermes en place en tant quéléments intégraux et requis de la productivité de lécosystème, faisant en sorte que les décisions portant sur l'abattage des arbres et leur conservation reposent sur un ensemble unique de critères de sélection. La façon dont ils perçoivent les arbres joue un rôle déterminant dans les décisions quotidiennes d’aménagement prises au niveau local, ce qui en retour influence l'aspect de lécosystème sur une base régionale. Le principal objectif de cette recherche porte sur la perception que les producteurs du Ghana ont des arbres forestiers dans les zones cultivées pour le cacao. Les données de cette recherche ont été recueillies au moyen d'une étude de cas exploratoire qui combinait les techniques d'ethnographie et de sondage, à partir de 34 entrevues de producteurs, de 34 relevés de ferme et d’entrevue avec les principaux informateurs représentant les intérêts des différents intervenants du territoire ancestral Domeabra des Ashanti-Akim, situé dans le centre sud du Ghana. Les données de recherche ont été analysés afin d'identifier les principales fonctions des arbres forestiers telles que perçues par les participants de létude, à la fois en tant que composante biophysique au sein de lécosystème agricole que délément de léconomie rurale.

Mots clés : paysage de cacaoyer, attitudes et perceptions des arbres, rétention d’arbres, production de cacao au Ghana, couvert de cacaoyer

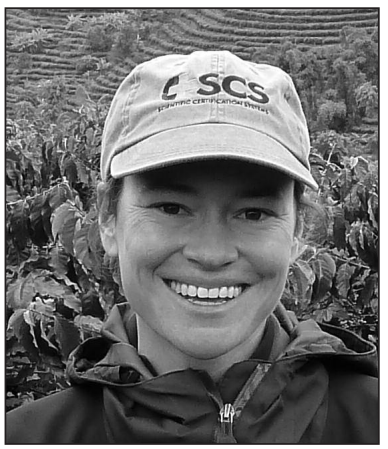

Jane E. Atkins

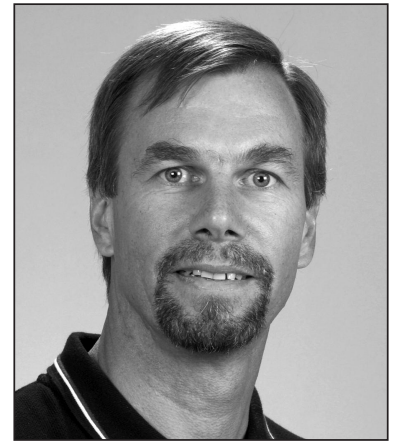

Ivan Eastin

\footnotetext{
${ }^{1}$ Manager, Sustainability Services, Food and Agriculture Division, SCS Global Services, 2000 Powell St., Suite 600, Emeryville, CA 94608, USA. E-mail: jatkins@scsglobalservices.com

${ }^{2}$ Director and Professor, Center for International Trade in Forest Products (CINTRAFOR), School of Environmental and Forest Sciences, Box 352100, University of Washington, Seattle, WA 98195-2100, USA. Author of correspondence. E-mail: eastin@uw.edu.
} 


\section{Introduction}

Cocoa cultivation accounts for the primary source of income for $11 \%$ of Ghana's population (Gibson 2007). Throughout a series of political and economic changes, cocoa cultivation has remained in the hands of smallholder farmers (Mikell 1992). However, lack of technical and financial capacity among smallholder farmers limits their ability to implement good farming practices, such as simple farm hygiene and tree pruning that would increase productivity, leading farmers to depend on expansion rather than intensification to increase total yield volumes (Padi and Owusu 1998).

Additionally, the depletion of available timber stocks (Hansen and Treue 2008) has put pressure on cocoa farms as the timber industry increasingly looks to the trees on cocoa farms to supply the demand of the wood processing sector (Owubah et al. 2001). Traditional tenure structures often prevent farmers from capturing the value of the timber trees on the open market, bringing them into conflict with the timber industry, and accelerating deforestation of the secondary forest canopy (Owubah et al. 2001). These changes in the forest structure and microclimate threaten the long-term viability of cocoa cultivation as it is currently practiced (Ruf and Schroth 2004, Franzen and Borgerhoff Mulder 2007), undermine the ecological benefits of the traditional shade-grown cocoa agroforestry system (Asare and Asare 2008), and contribute to the degradation of the secondary forest ecosystem (Padi and Owusu 1998).

Often a lack of awareness about the full range of contributions from indigenous forest trees, both ecological and economic, may be driving change within the landscape towards a more "technified" agroforestry regime that favours plantation-style rows of sun-tolerant cocoa trees (Rice and Greenberg 2000). While the livelihoods of farmers depend on increased yields and productivity, frequently achieved through expansion and/or adoption of newer hybrid cocoa varieties, these short-term outcomes must be weighed against the long-term opportunity costs, in this case increased deforestation and forest degradation, increased dependence on agrochemicals, and the shorter life cycles of cocoa trees grown in full sun. Farmers' lack of access to price premiums provided by certification schemes such as "organic" or "bird friendly" limits the efficacy of a purely market-based approach to influencing on-farm cultivation practices. In this environment, efforts to reduce forest degradation through improved agroforestry methods on cocoa farms must take into account farmer perceptions of trees in order to provide effective incentives for the retention of a diverse shade canopy.

\section{Research Questions and Objectives}

This exploratory research had two primary objectives. The first objective was to understand how cocoa farmers perceive naturally occurring forest trees within their cocoa farms, both with respect to their biophysical interactions with cocoa trees and their economic contributions to farmer livelihood. The second objective looked to offer recommendations for encouraging the retention of trees on cocoa farms. By drawing out farmer perceptions of forest trees, this exploratory study seeks to clarify farmers' perceptions of the broad range of challenges and benefits forest trees provide within the cultivated cocoa landscape and the rural economy. In exploring the role of the trees and their value, both economic and environmental, from the perspective of farmers themselves, this research offers insight into the many contributions trees make, and exposes gaps in farmers' understandings of the benefits provided by trees. This information can provide guidance for the development of future management strategies in off-reserve forest areas, as well as improving the livelihood of farmers through improved agroforestry practices.

\section{Research Methods and Data Analysis}

This research was designed using an exploratory case study approach (Yin 2003) and was conducted entirely within the Domeabra Traditional Lands in the Konongo District, Ashanti-Akim. Thirty-four farmer interviews and two additional interviews were conducted with a chainsaw logger and the manager of a local sawmill between February 8 and March 2, 2010. Farmer interviews were conducted with individual cocoa farmers and took place on the respective farms of the individual being interviewed.

All farmer interviews followed the same format. The first part of the interview collected farmer-level data through the use of open-ended questions to obtain basic demographic information about the farmer, learn the history of the farm, the respondent's reasons for choosing to farm cocoa, basic information on cultivation methods, and general attitudes regarding the importance of shade to the farm and the farmer. Following the completion of the personal interviews, walking interviews were conducted during a survey of individual trees on each farm. These questions were designed to learn about farmers' perception of their agency over trees, their willingness to retain trees on the farm and any experiences with unauthorized tree removal that might affect their attitudes towards tree retention on their farm.

The interview data from the 34 farmer interviews were coded using grounded theory (Auerbach and Silverstein 2003). Coding was conducted twice, first using Microsoft Word to cut and paste emergent themes into new documents, and then using Nvivo 8 software to develop emergent themes into nodes. Employing an exploratory approach to data analysis, the contents of the interviews were carefully coded for thematic relevance within the framework of the research objectives.

\section{Results}

\section{Farm characteristics}

More than half (24) of the farms surveyed had been established within the past 15 years, partly due to the devastating bush fires that swept through the region in 1983 (Fig. 1). As a result of the fires, much of the land that was under cocoa cultivation was abandoned to bush fallow, although a few farms were used to grow foodstuff. The older farms included in the survey were either planted just after the fire, or they were located in an area that was not affected by the fires. The average size was 2.65 ha.

The cocoa farms surveyed contained an average of 23 living forest trees per ha. While this average value is consistent with the recommendations of the Cocoa Research Institute of Ghana (CRIG), calculating the average desired trees per ha, as expressed by the surveyed cocoa farmers, yielded a lower figure of eight trees per ha (Fig. 2). Of the 1440 trees observed on the farms visited, 1209 were living indigenous forest trees, 


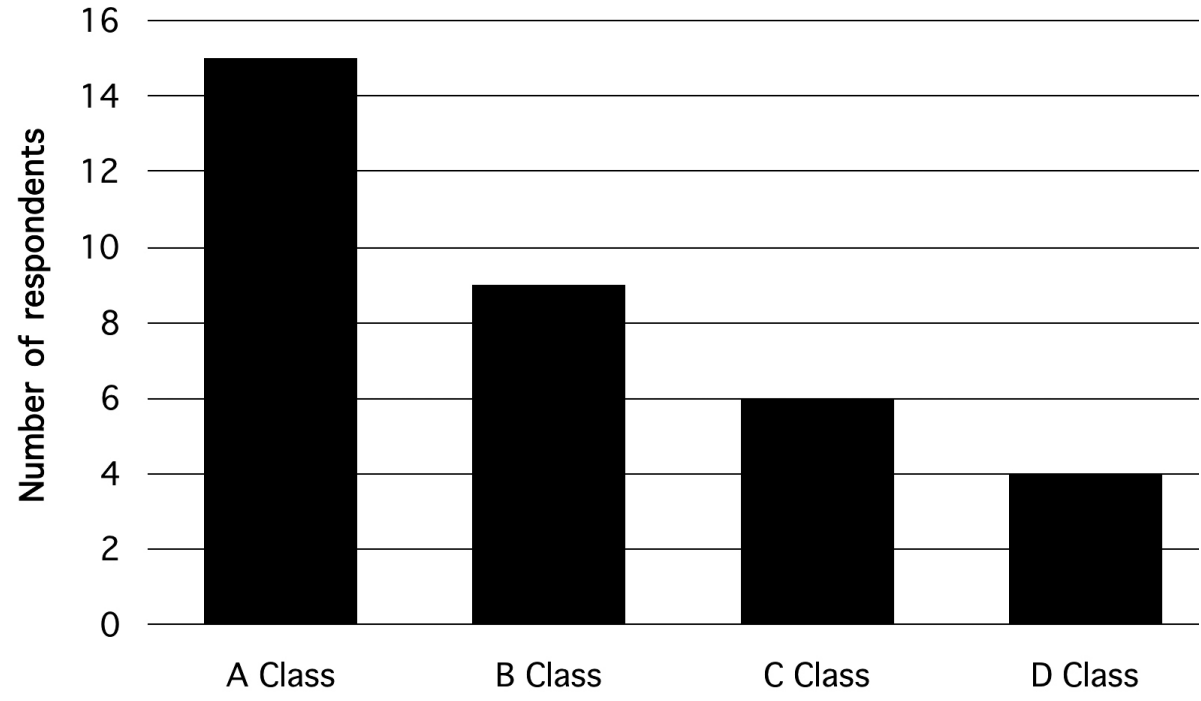

Fig. 1. Age class distribution of cocoa farms surveyed. (Class A (0-7 years), Class B (8-15 years), Class C (16-30 years), and Class D (>30 years)].

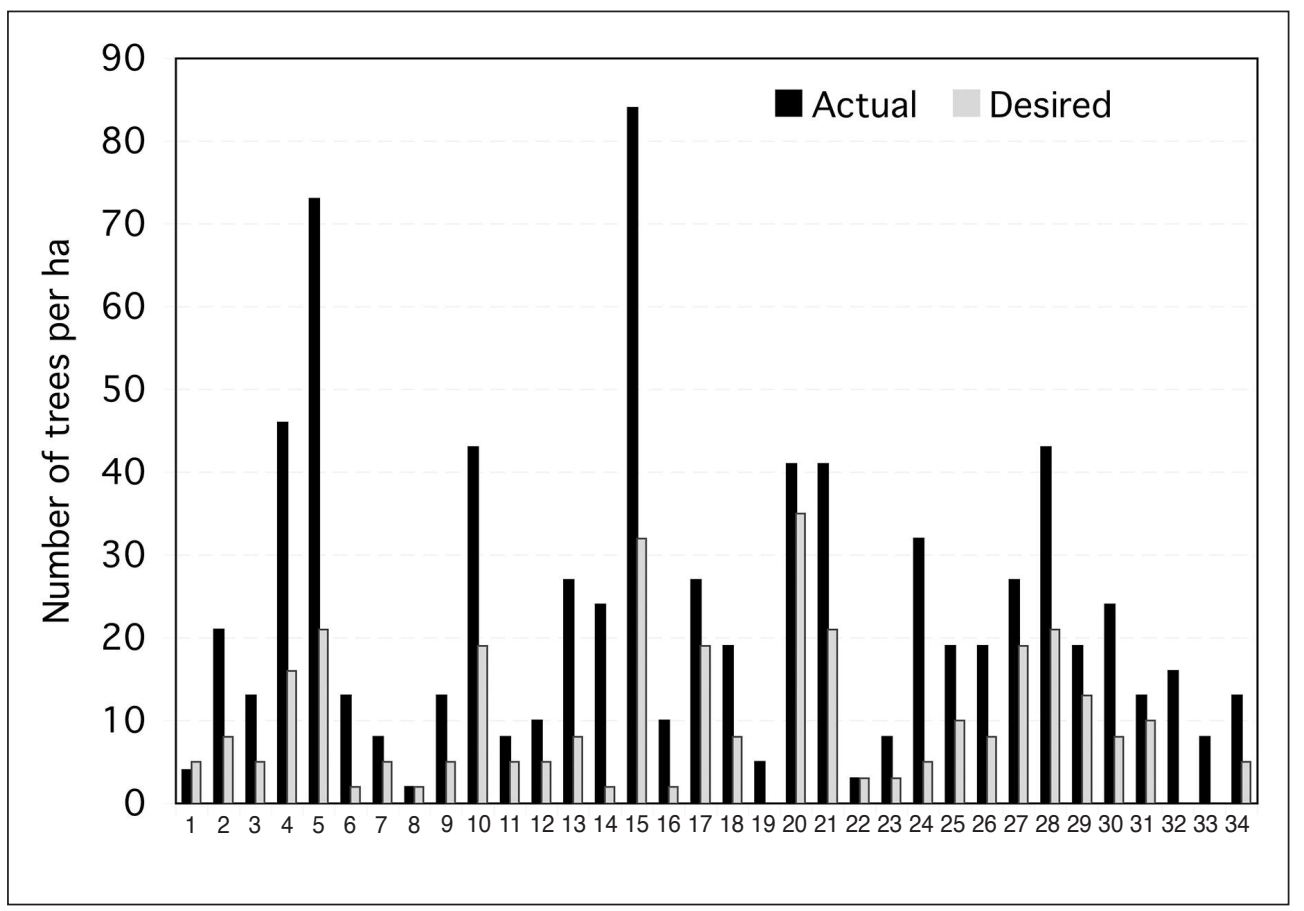

Fig. 2. Number of actual trees on cocoa farms and desired number of trees

91 were dead indigenous forest trees, and 140 were planted fruit or medicine trees (Table 1). In total, 67 species of indigenous forest trees were observed.

Hybrid (sun-tolerant) cocoa was the dominant variety of cocoa planted on farms in this study (19), while eight farms were planted with an Amazonia variety, three with a hybrid/Amazonia mix, two with a hybrid/amelonado mix, one with a amelonado/ Amazonia mix, and one with an unspecified mix ("all varieties"). In cases in which the farm was planted with a cocoa variety other than newer suntolerant cocoa hybrid variety, the farmer was replacing senescent trees with the hybrid variety. Among farmers interviewed, hybrid was favoured for its earlier fruiting onset and increased seasonal productivity, in some cases despite other benefits, such as increased longevity and resilience to drought or pests, offered by older varieties such as amelonado or Amazonia.

Of the 34 farms surveyed, 27 were inherited from a family member; three were in a sharecropping arrangement; and four had been purchased outright. All of the farmers reported being natives of Domeabra, in which case they enjoy customary rights to farm the land through family lineages.

Farmer demographic characteristics

The sample frame consisted of 34 farmers: 31 men and 3 women. The age of the farmers interviewed ranged from 31 to 85 , with the majority in the 41- to 70-year-old age group. The age group with the most farmers (12) was 41 to 50 years old and 20 farmers reported having a career prior to becoming a cocoa farmer. Most of the farmers indicated that they went into cocoa farming as an intentional choice, primarily because it is widely perceived to provide a reliable source of income.

"Cocoa farming is one of richest way to get money in Africa, especially Ghana. You see it's a cash crop so you can rely on it. It's a long-term project, so that's why I'm interested too." 
Table 1. Categories of non-cocoa trees observed on surveyed farms

\begin{tabular}{lccc}
\hline Category & Keep & Remove & Total \\
\hline Live indigenous forest trees & 512 & 636 & 1209 \\
Dead indigenous forest trees & n/a & 91 & 91 \\
Planted exotic trees & 110 & 30 & 140 \\
\hline & $\mathbf{6 2 2}$ & $\mathbf{7 5 7}$ & $\mathbf{1 4 4 0}$ \\
\hline
\end{tabular}

Table 2. Summary of perceptions of trees as a biophysical component of the farm

\begin{tabular}{lcc}
\hline & Positive & Negative \\
\hline $\begin{array}{l}\text { Respondents citing general } \\
\text { biophysical attributes } \\
(\mathrm{N}=34)\end{array}$ & $27(79 \%)$ & $20(59 \%)$ \\
$\begin{array}{l}\text { Biophysical ratings of } \\
\text { specific trees }(\mathrm{N}=1209)\end{array}$ & $616(51 \%)$ & $487(40 \%)$ \\
\hline
\end{tabular}

Of the 12 farmers in the 41- to 50-year-old age group, only five reported coming into farming from a previous career, while seven stated that they had chosen cocoa farming from the beginning of their career. This is in contrast to the 51- to 60 -year-old age group, in which seven of the eight farmers reported having a previous career. Reponses gathered through farmer interviews suggest that for those coming to farming as a second career, farming is viewed as a more secure long-term livelihood than their previous occupation.

"I realized that work [mechanic] wouldn't help me in nearby future, so I stopped that work, and I started farming. Also I am having two kids now, and I wanted property for my kids, so that any time if I go, my children will not be wanting." [farmer, age 35]

"I am old now, and I am having children, and I can't sit down for the children not to do anything. So I started cocoa to help take children to school. And also if I'm not there, the children can inherit it." [farmer, age 49]

\section{Farmer's perceptions of trees}

In the most general sense, responses gathered during the interviews suggest that farmer's perceptions of indigenous shade trees on their cocoa farms are both positive and negative. To further analyze this, we grouped data on tree perceptions from farmer interviews and farm surveys into two categories: trees as a biophysical object and trees as a social object. "Trees as a biophysical object" includes perceptions related to the functions of trees within the farm ecosystem. "Trees as a social object" includes perceptions of trees beyond the biophysical, and beyond the farm boundary. This includes economic compensation for trees, investment in trees, non-timber forest products derived from trees, and theft or conflict related to trees.
Trees as a biophysical component within the farm ecosystem

In order to address farmers' perceptions about the role of trees as a biophysical object within the farm ecosystem, responses were coded into two categories: positive statements and negative statements. Positive statements reference benefits provided by the trees to the cocoa farm, while negative statements reference harmful effects of trees on the cocoa farm. Respondents were probed as to both negative and positive opinions within the context of the interview (Table 2).

Among respondents relying on natural regeneration of indigenous trees for recruitment of shade, a decision process emerged. The decision to retain naturally regenerating young trees was based on (1) their biophysical contribution to the farm; (2) their economic contribution to the farmer's livelihood; and (3) their medicinal or nutritive contribution to the farmer's diet. Data collected in the tree survey confirmed this decision hierarchy; of the 1209 indigenous forest trees growing on the 34 cocoa farms visited, farmers rated 1148 as being either "good for cocoa" (616 observations) or "bad for cocoa" (487 observations), while no opinion was offered on just 61 trees.

It is not possible to further define individual tree species based on perceived "goodness" or "badness", because perceptions were not consistent within even this small group of cocoa farmers. In contrast, comparisons can be made between tree species to examine whether the perceived "goodness" or "badness" of a species influences the cocoa farmers decision to keep or remove a tree. The survey results show that those trees that were perceived as being bad for cocoa were targeted for removal $90 \%$ of the time whereas trees rated as being good for cocoa were targeted for removal just $30 \%$ of the time (Table 3 ).

The data in Table 3 were further analyzed using a binomial comparative trial where a $\chi^{2}$ test of independence was run on each of the sub-groups, "good for cocoa" and "not good for cocoa" to determine if timber or non-timber characteristics were independent of the decision to harvest a tree within each respective sub-grouping (Zar 1999). The results of the test show that respondents were significantly less likely to fell an indigenous tree if they perceived it as being both good for cocoa and having a timber value. No other findings were significant.

\section{Positive perceptions of trees}

The survey results found 34 references from 27 farmers regarding the biophysical benefits provided by trees, while the

Table 3. Tree rating and intent to fell

\begin{tabular}{|c|c|c|c|c|c|}
\hline \multirow[b]{2}{*}{$\begin{array}{l}\text { Intent } \\
\text { to fell }\end{array}$} & \multicolumn{2}{|c|}{ "good for cocoa" } & \multicolumn{3}{|c|}{ "not good for cocoa" } \\
\hline & Timber & $\begin{array}{l}\text { Non- } \\
\text { timber }\end{array}$ & Timber & $\begin{array}{l}\text { Non- } \\
\text { timber }\end{array}$ & Total \\
\hline Yes & $60^{\mathrm{a}}$ & 139 & 254 & 183 & 636 \\
\hline No & 254 & 208 & 30 & 20 & 512 \\
\hline Total & 314 & 347 & 284 & 203 & 1148 \\
\hline
\end{tabular}

${ }^{\mathrm{a}} \chi^{2}=34.37$ 


\begin{tabular}{lcl}
\hline Benefit Perceived & Frequency & Common species in this group \\
\hline Provides good shade & 505 & Morinda lucida, Funtumia elastica, Holarrhena floribunda \\
Improves soil fertility & 40 & Morinda lucida, Spathodea campanulata \\
Does not compete with cocoa & 36 & Morinda lucida, Funtumia elastica, Holarrhena floribunda \\
Gives water & 26 & Spathodea campanulata, Ficus exasperata \\
Protects the land & 22 & Newbouldia laevis, Pycnanthus angolensis \\
Provides good ventilation & 12 & Pycnanthus angolensis \\
Provides integrated pest management & 5 & Funtumia elastica, Cola nitida \\
\hline
\end{tabular}

Table 5. Perceived negative attributes of individual trees

\begin{tabular}{lcl}
\hline Negative perception & Frequency & Common species in this group \\
\hline Too much shade & 105 & Albizia zygia, Blighia sapida, Pycnanthus angolensis \\
Absorbs too much water & 89 & Albizia zygia, Ficus exasperata, Sterculia tragacantha \\
Branches fall & 59 & Albizia zygia, Antiaris toxicaria \\
Attracts pests & 55 & Sterculia tragacantha \\
Takes too much space & 30 & Ceiba pentandra, Rauvolfia vomitoria \\
Told by extension & 20 & Albizia zygia \\
Competes for nutrients & 17 & Ficus exasperata, Duakoben (scientific name unknown) \\
\hline
\end{tabular}

farm survey data indicates that 616 trees were perceived as being "good for cocoa", (Table 4). Responses regarding the positive benefits of trees within the cocoa farm could be grouped into one of three categories: 1) protect cocoa trees from sunlight (mentioned 23 times); 2) reduce soil erosion/improve soil fertility (six); and 3) improve air flow within the cocoa farm (four). The results clearly show that most of the farmers interviewed perceived that the primary benefit of trees within the cocoa farm was to provide shade for cocoa trees.

Farmers categorized the threat to the cocoa tree from overexposure to direct sunlight as falling into one of two categories: drying out the leaves of the cocoa tree itself; or drying out the soil and harming the cocoa indirectly.

"[Trees] prevent direct sunlight from reaching the cocoa. Direct sunlight will damage the cocoa tree. When it is very hot, it makes the land very dry, and absorbs water content in soil, make it difficult for cocoa to survive."

While only six respondents cited soil protection or soil enrichment during the introductory interview, during the tree survey 40 trees were rated as having soil-enriching qualities due to leaf litter or fruit fall from the tree. As with soil protection, this may indicate that respondents perceive the benefits of trees for enhancing soil fertility on an individual basis. Of the two respondents citing soil enrichment during the introductory interview, both worked older farms that had been under cultivation for some time prior to the farmer acquiring the farm.

Four respondents noted that shade trees improved ventilation within the cocoa farm. They explained this as the trees giving the cocoa trees a "nice breeze". This theme was repeated in the observations from the tree survey, in which 12 trees were perceived as beneficial due to their ability to improve ventilation. The retention of shade canopy may contribute to increased airflow through the farm, which could have an effect of reducing incidence of black pod disease.

\section{Negative perceptions of trees}

The survey results found 28 references from 20 farmers regarding the negative biophysical impacts provided by trees, while the farm survey data indicates that 487 trees were perceived as being "not good for cocoa", Table 5. Four farmers perceived trees only as a negative biophysical component of their cocoa farm whereas 16 farmers mentioned both positive and negative aspects of trees within their cocoa farms. Responses regarding the negative benefits of trees within the cocoa farm could be grouped into one of three categories: 1) competition with cocoa trees (mentioned eight times), 2) reducing the yield of cocoa trees (eight) and 3) increasing the occurrence of black pod disease within the cocoa farm (seven).

In talking with the cocoa farmers during the farm visits there emerged certain trees that respondents almost always intended to remove. The most frequently cited of these was the okoro tree (Albizia zygia [DC.] J. F. Macbr.). In 92 observations of $A$. zygia on the cocoa farms visited, farmers expressed their intention to cut down the tree in 87 cases (95\% of the time). The bias against okoro is related to the fact this tree has heavy branches that often fall and brittle wood that splinters easily, causing substantial damage to the cocoa trees in the understory. In addition, the wood from the okoro tree does not have any commercial uses. Despite the fact that okoro is a pioneer leguminous tree species that can fix nitrogen in nutrient depleted soils, cocoa farmers often remove this tree once it reaches a certain height.

Other trees that farmers almost always intended to remove included Ficus species (a "thirsty" tree) and Sterculia traga- 
cantha Lindl. Farmers intended to remove members of the Ficus genus in 90 of 109 cases (83\% of the time) because it absorbs too much water. S. tragacantha was planned for felling in 64 out of 71 cases ( $90 \%$ of the time). It is a tree that has a large crown and a dense canopy that limits sunlight availability within the cocoa farm. Excessive shade was also reported to contribute to the occurrence of black pod disease-a highly contagious and devastating fungal disease.

In summary, respondents perceive trees as both a positive and negative ecological component within the farm ecosystem, and they also draw on trees as an important source of timber. Respondents perceive trees to function as a protective element to shield the cocoa from direct sunlight, but also consider some trees to reduce farm productivity by inhibiting fruit development and encouraging diseases and pests. Thus, most farmers seek a balance between too many and too few trees, while also considering the contributions of individual trees based on timber characteristics. While farmers may access advice as to the correct number of trees per ha, they ultimately make this selection from personal preference, and from reading the conditions on their farm.

\section{Trees as an input to the rural economy}

Trees contribute to the economic well-being of individual farmers and the local community by providing timber and non-timber products to be traded, sold, or personally used. They also function as a social commitment to future generations, and are nurtured as an investment.

\section{"When I started preparing land to plant, I sold three trees to chainsaw operators and used the money to start the farm."}

Trees are an important asset to the farmer that can be liquidated easily to supplement farm income. Trees contribute economically both through a direct conversion to capital (selling outright) or through offsetting a planned expense, such as house-building, by providing raw materials that otherwise would have to be purchased. Trees also contribute important non-timber forest products that supplement the livelihoods of the farmers interviewed. In fact, of 1209 indigenous forest trees observed, $964(\sim 80 \%)$ were perceived as having value to the farmer aside from their ecological impact within the cocoa farm.

\section{Trees as an investment in the future}

In the absence of a strong rural economy that provides opportunities for wealth accumulation, trees are perceived as a kind of "growing capital" that provides a hedge against future uncertainty and symbolizes intergenerational continuity. Ashanti farmers have a multi-generational commitment to the landscape, and current landowners are part of a familial relationship to the land that stretches forward and back in time. This perception of trees as a physical symbol of intergenerational commitment was particularly evident among older farmers. One farmer, in his 80 s, indicated that he had been farming the same piece of land for 40 years, and that he had inherited the farm from his forefathers. His forefathers left him timber trees, which he used to build his house, and he intended to do the same for his nephews, to whom he would pass on the land.

\section{Discussion}

Cocoa agroforestry as it is practised in Domeabra is in transition from a rustic system carried out beneath the canopy of the intact secondary forest, to a technified system in which land is cleared and burnt, and cocoa is planted under light shade of plantain or a reduced quantity of retained forest trees. In using trees to subsidize start-up costs, farmers are removing valuable species that would provide important ecological benefits. Farmers are simultaneously moving towards adoption of sun-tolerant hybrid varieties that are perceived as requiring less shade and producing higher cocoa yields. In choosing to move towards higher-yielding hybrid cocoa varieties, farmers are trading the increased ecological resilience of older cocoa varieties and the benefits of growing under a diverse shade canopy (including access to NTFPs and raw material for wood products) for more sensitive hybrid varieties of cocoa in the hope that this transition will lead to increased productivity and increased revenue.

Trees as a biophysical component within the farm ecosystem Indigenous forest trees retained on the landscape can provide a number of benefits including improved nutrient cycling and increased biomass (Isaac et al. 2007), reduced soil erosion, enhanced profitability and ecological resilience (Duguma et al. 1998), and reduce pathogen and insect attack (Bos et al. 2007). Overall, perceptions of trees as a biophysical component of the farm were surprisingly limited, and tended to focus rather narrowly on shade provision without acknowledging the myriad benefits to soil fertility, erosion control or integrated pest management. In addition, negative perceptions were varied and inconsistent, suggesting that negative perceptions may not be based on causal observation but rather individual preference.

\section{Trees as an economic and social object}

In contrast to the thin and poorly distributed understandings of the biophysical perceptions of trees, the economic and social perceptions of trees reported by farmers were rich and varied. Farmers' perceptions of trees as an integral component of their livelihood were representative of traditional ecological knowledge accumulated over hundreds of years in a subsistence society. Forest dwellers in the Ashanti Region have long depended on the wealth of natural resources from the forest to provide medicine, food, shelter, and other goods to sustain themselves (Wilks 1993). Their connection to trees in this respect was intimate and deep. This was reflected in the exhaustive inventory of the uses of trees aside from their biophysical interactions with cocoa. In fact, almost all of the farmers interviewed demonstrated a positive perception of trees as assets for increasing personal wealth, for providing building materials and other goods, and for representing commitment to future generations. In this respect, cocoa agroforestry, as it is practised in the study area, substantiated representations in the literature of agroforestry as providing diverse goods to farmers (Winterbottom and Hazlewood 1987). Efforts to encourage tree retention on cocoa farms should build on and reinforce this traditional knowledge.

Not all trees are equal: selecting shade trees for the farm Overall, farmers in this study are moving towards a less shaded, less diverse cocoa landscape that may reduce the 
long-term sustainability of cocoa farming in Domeabra. This trend may also have an adverse impact on deforestation and forest degradation because, currently, retained indigenous trees on cocoa farms are fulfilling the demands of the local market for building materials and other wood products. As trees on cocoa farms disappear as a resource, the demand for these products will have to be met elsewhere, increasing the harvesting pressure on Ghana's strained forest reserves. Educating farmers about the benefits of trees for the farm ecosystem and providing improved incentives for tree retention will help farmers and the forest, improving the long-term ecological, social, and economic sustainability of cocoa agroforestry in the Domeabra Traditional Lands.

\section{Conclusions}

The findings from this study reinforce the need to educate farmers on the ecological and economic benefits of retaining trees on their farms. All of the farmers interviewed in this study indicated that their perceptions of trees, positive or negative, affected their management decisions. While the timber value of a tree influenced the farmers' decisions to retain the tree, the perception that a tree was "bad for cocoa" was a more influential consideration and increased the probability that the farmer would remove the tree.

Deforestation and forest degradation in Ghana pose serious threats to the livelihood of its many forest-dependent communities and to the survival of its many endemic flora and fauna species. In addition, the national economy depends heavily on cocoa and timber to provide export revenue and jobs. Reducing forest loss due to the expansion and degradation of the cocoa landscape is possible, given the substantial resources in both the forestry and cocoa sectors within the country. While this may not help the export-oriented timber industry, it would help rural farmers to diversify incomes, provide the domestic market with a continuing supply of wood, and protect the valuable forest soils that sustain the cocoa economy. If these interests can align, the long-term outcomes for forests and for people will improve.

\section{References}

Asare, R. and R. Asare. 2008. A Participatory Approach for Tree Diversification in Cocoa Farms: Ghanaian Farmers' Experience. Sustainable Tree Crops Program. STCP Working Paper Series, Issue 9.

Auerbach, C.F. and L.B. Silverstein. 2003. Qualitative Data: An introduction to coding and analysis. New York University Press, New York.
Bos, M.M., I. Steffan-Dewenter and T. Tscharntke. 2007. Shade tree management affects fruit abortion, insect pests and pathogens of cacao. Agriculture, Ecosystems \& Environment 120: 201-205.

Duguma, B., J. Gockowski and J. Bakala. 1998. Smallholder cocoa cultivation in agroforestry systems of West and Central Africa. Paper presented at Shade Grown Cacao Workshop, hosted by the Smithsonian Migratory Bird Center/Smithsonian Tropical Research Institute, Panama City, Panama, 30 March 1998.

Franzen, M. and M. Borgerhoff Mulder. 2007. Ecological, economic, and social perspectives on cocoa production worldwide. Biodiversity Conservation 16: 3835-3849.

Gibson, J. 2007. Consistently Inconsistent: Addressing income volatility among cocoa producers in Ghana and Cote d'Ivoire. International Institute for Sustainable Development.

Hansen, C.P. and T. Treue. 2008. Assessing Illegal Logging in Ghana. International Forestry Review 10(4): 573-590.

Isaac, M.E., V.R. Timmer and S.J. Quashie-Sam. 2007. Shade tree effects in an 8-year-old cocoa agroforestry system: biomass and nutrient diagnosis of Theobroma cacao by vector analysis. Nutrient Cycling in Agroecosystems 78: 155-165.

Mikell, G. 1992. Cocoa and Chaos in Ghana. Howard University Press, Washington, DC.

Owubah, C.E., D.C. Le Master, J.M. Bowker and J.G. Lee. 2001. Forest Tenure Systems and Sustainable Forest Management: the case of Ghana. Forest Ecology and Management 149: 253-264.

Padi, B. and G.K. Owusu. 1998. Towards an Integrated Pest Management for Sustainable Cocoa Production in Ghana. Paper presented at Shade Grown Cacao Workshop, hosted by the Smithsonian Migratory Bird Center/Smithsonian Tropical Research Institute, Panama City, Panama, 30 March 1998.

Rice, R.A. and R. Greenberg, 2000. Cacao Cultivation and the Conservation of Biological Diversity. Ambio 29(3): 167-173.

Ruf, F. and G. Schroth. 2004. Chocolate Forests and Monocultures: A Historical Review of Cocoa Growing and Its Role in Tropical Deforestation and Forest Conservation. In G. Schroth, G.A.B. da Fonseca, C.A. Harvey, C. Gascon, H.L. Vasconcelos and A.-M.N. Izac (eds.). Agroforestry and Biodiversity Conservation in Tropical Landscapes. Island Press, Washington, DC.

Wilks, I. 1993. Forests of Gold: Essays on the Akan and the Kingdom of Asante. Ohio University Press, Athens, $\mathrm{OH}$.

Winterbottom, R. and P.T. Hazlewood. 1987. Agroforestry and Sustainable Development: Making the Connection. Ambio 16(2/3): $100-110$.

Yin, R.K. 2003. Case Study Research: Design and Methods ( $3^{\text {rd }}$ ed.). Sage Publications, Inc., Thousand Oaks, CA.

Zar, J.H. 1999. Biostatistical Analysis, $4^{\text {th }}$ Edition. Prentice Hall, Upper Saddle River, NJ. 